\title{
Bingöl İli Kent Merkezinde Açık Süt (Sokak Sütü) Tüketim Durumunun Belirlenmesi
}

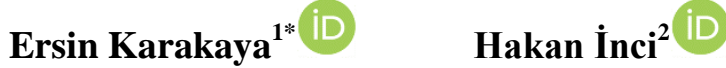 \\ ${ }^{1}$ Bingöl Üniversitesi Ziraat Fakültesi Tarım Ekonomisi Bölümü, Bingöl \\ ${ }^{2}$ Bingöl Üniversitesi Ziraat Fakültesi Zootekni Bölümü, Bingöl \\ *Sorumlu yazar: karakayaersin@ hotmail.com
}

Geliş Tarihi: 04.05.2020

Kabul Tarihi: 01.12.2020

\section{$\ddot{\mathbf{O} z}$}

$\mathrm{Bu}$ çalışmanın amacı, Bingöl ili kent merkezinde ailelerin açık süt tüketim miktarını ve tercihlerini belirleyerek, bu süt tipi tercihleri üzerine etkili olan sosyo-ekonomik ve demografik faktörleri saptamaktır. Çalışmanın birincil verilerini Bingöl kent merkezindeki tüketicilerden 2018 yılında yüz yüze elde edilen anket verileri oluşturmaktadır. Araştırma bulgularına göre; tüketicilerin \%68,2'sinin açık süt tükettiği belirlenmiştir. Anket yapılan tüketicilerin aylık gıda harcaması ortalama 1047,30 TL, aylık açık süt tüketim miktarı ortalama $14,24 \mathrm{~kg}$ ve aylık açık süt tüketim harcaması ise ortalama 31,67 TL olarak belirlenmiştir. Yıllık açık süt tüketimi 170,88 lt ve açık süt tüketim harcaması ise 380,04 TL olarak hesaplanmıştır. Kişi başı yıllık açık süt tüketimi 38,31 lt, açık süt tüketim harcaması ise 85,21 TL olarak saptanmıştır. Anket yapılan tüketicilerin tamamının açık süt tüketimi ile ilgili olan faktörlerin hepsini önemli buldukları sonucuna varılmıştır. Sonuç olarak; açık süt üretimi ve tüketimi ile ilgili verileri ortaya koyan çalışmaların yapılarak, insan sağlı̆̆ı, gıda güvenliği ve tarımsal üretim konusunda stratejilerin belirlenmesi son derece önemlidir.

Anahtar Kelimeler: Açık süt, Bingöl, gıda harcaması, tüketim

\section{Determination of Raw Milk Consumption Status in Bingöl City Center}

\section{Abstract}

The aim of this study is to determine the amount of raw milk consumption of families, their preferences and socio-economic and demographic factors that affect these milk type preferences in the city center of Bingol. The primary data of the study consisted of face-to-face survey data obtained from consumers in Bingol city center in 2018. According to the research findings; $68.2 \%$ of consumers were found to consume raw milk. The monthly food expenditure of the surveyed consumers was determined as $1047.30 \mathrm{f}$, the monthly raw milk consumption amount was $14.24 \mathrm{~kg}$ and the monthly raw milk consumption expenditure average was $31.67 £$. Annual raw milk consumption was calculated as 170.88 liters, and raw milk consumption was calculated as 380.04€. Annual raw milk consumption per capita was determined as $38.31 \mathrm{lt}$, and raw milk consumption was 85.21€. It was concluded that all of the factors related to raw milk consumption are important for all surveyed consumers. As a result; the determination of strategies on human health, food safety and agricultural production by conducting studies that reveal data on raw milk production and consumption is extremely important.

Keywords: Bingol, consumption, food expenditure, raw milk

\section{Giriş}

Doğumdan başlayarak insan yaşamının bütün aşamalarında gerekli olan süt, $\mathrm{C}$ vitamini ve demir dışında makro ve mikro besin öğelerini barındıran iyi bir kaynaktır. Özellikle çocukluk, gebelikemziklilik ve yaşlılık dönemlerinde kemik sağlığı açısından sütün faydası vardır (Black ve ark 2002; Ünal ve Besler, 2012; Kahraman, 2016). Sütün elde edildiği hayvan türüne bağl1 olarak ana besin öğelerinin, çok değişkenlik gösterdiği; kuru madde oranının \%11,2 ile \%37,5; süt yağının \%1,8- \%22; protein oranının \%1- \%15,5 aralığında değiştiği belirlenmiştir (Metin, 2012; Kahraman, 2016). Türk Gıda Kodeksi Yönetmeliği gereğince hazırlanan "Çiğ Süt ve Işıl İşlem Görmüş Sütler Tebliğinde" (2000/6-RG:14.02.2000/23964) çiğ süt; "Bir veya daha fazla inek, keçi, koyun veya mandanın sağılmasıyla elde edilen, $40^{\circ} \mathrm{C}$ 'nin üzerine 1 sitılmamış veya eşdeğer etkiye sahip herhangi bir işlem görmemiş kolostrum dışındaki meme bezi salgısı" şeklinde tanımlamıştır. 2019 yılında sağılan toplam (yerli ve merinos) koyun sayısı 19836985 baş ve süt üretimi ise 1521455 ton olarak gerçekleşmiştir. Sağılan toplam (Kıl ve Tiftik) keçi sayısı 5471086 baş ve süt üretimi ise 577208 ton olarak gerçekleşmiştir. Sağılan toplam (melez, yerli ve kültür) sığır sayısı 6580753 baş ve süt üretimi ise 20 
782374 ton olarak gerçekleşmiştir. Özellikle kültür ve melez sığırlarının sayısına bağlı olarak süt üretimi sürekli artış göstermiş, 2015 ve 2016 yıllarında hem kültür hem de melez sığır sayısının azalmasına bağlı olarak süt üretimi azalmıştır. Yerli sı̆̆ır sayısı ise 2012 yılından itibaren azalmaya başlamasına rağmen süt üretimini olumsuz etkilemediği belirlenmiştir.

Türkiye'de büyükbaş hayvan başına ortalama 3 ton, Bingöl'de ise ortalama 2,35 ton süt üretimi gerçekleşirken, hem Türkiye hem de Bingöl'de küçükbaş hayvan başına ortalama 0,08 ton süt üretimi gerçekleşmiş̧ir. Türkiye'de 2018 yılında üretilen 22,1 milyon ton çiğ sütten 1,66 milyon ton içme sütü, 110 bin ton süt tozu, 65 bin ton tereyağı, 756 bin ton peynir, 1,20 milyon ton yoğurt ve 730 bin ton ayran üretildiği bildirilmiştir (SETBİR, 2018). Avrupa Birliği (AB) ülkeleri arasında y1llık ortalama süt tüketimi 60 litrenin üzerinde iken, Türkiye, büyük baş hayvan sayısı ve süt üretiminde üst sıralarda yer almasına rağmen süt tüketiminde ise $\mathrm{AB}$ ortalamasının altında bulunmaktadır.

Açık süt; ucuz olması ve tüketicilerin kapısına kadar getirilmesinden dolayı tercih edilmektedir. İşlenmiş süt ise; kaliteli, garantili, hijyenik ve raf ömrünün uzun olmasının yanında tüketicinin kolayca depolayabildiği için tercih edilmektedir. Türkiye'de işlenmiş süt tüketimini sadece eğitim, yaş gibi demografik faktörler etkilememekte olup, ilaveten tüketicinin gida güvenilirliği, sağl1k bilinci ve yapılan reklamların da son derece önemli etkisi vardır (Akbay ve Tiryaki 2008; Uzundumlu ve Birinci, 2013).

Araştırma bölgesinde, genelde az sayıda süt hayvanına sahip olan ve ürettiği sütün açık bir şekilde satışını yapan birçok aile işletmesi bulunmaktadır. Dolayısıyla, bölgede açık süt satış1 yaygındır. $\mathrm{Bu}$ çalışmanın amacı, Bingöl ili kent merkezinde ailelerin açık-sokak sütü tüketim durumunu ortaya koyarak, açık süt tüketim tercihlerini belirlemek ve bu tercihleri etkileyen sosyoekonomik ve demografik faktörleri saptamaktır.

\section{Materyal ve Yöntem}

$\mathrm{Bu}$ araştırmanın birincil verilerini Bingöl kent merkezindeki tüketicilerden 2018 yılında elde edilen anket verileri oluşturmaktadır. İkincil veriler ise konu ile ilgili kamu kuruluşlarından, yerli ve yabancı bilimsel çalışmalardan, dergi ve çeşitli yayınlardan derlenmiştir. Bingöl ili kent merkezinde yaşayan tüketicilere sosyo demografik ve ekonomik soruların yanında, aylık açık süt tüketim miktarı, aylık açık süt tüketim harcaması, açık süt hakkındaki düşünceleri, açık süt tercih sebeplerini belirlemeye yönelik sorular sorulmuştur. Ankete katılan tüketicilerin süt tüketimine yönelik ifadelere katılım durumunun belirlenmesinde "onaylama düzeyi beş ölçekli likert" ölçeği kullanılmıştır. Likert türü ölçekleme tekniği, uygulamalı sosyal bilim araştırmalarında en sık kullanılan ölçekleme tekniği olup, kuruluşu ve uygulaması konusundaki titizlik araştırmanın sonuçlarının doğruluğu için önemlidir (Bayat, 2014). Aralıkların eşit olduğu varsayımı ile aritmetik ortalamalar için puan aralığı (En Yüksek Değer - En Düşük Değer) / 5 formülü ile hesaplanmıştır (Kaplanoğlu, 2014).

Puan Aralığ $1=(5-1) / 5=4 / 5=0,80$ olarak hesaplanmıştır. Ortalamalar için değerlendirme aralığ 1,00-1,80 önemli değil; 1,81-2,60 biraz önemli; 2,61-3,40 orta önemli; 3,41-4,20 oldukça önemli; 4,21-5,00 çok önemli şeklinde belirlenmiş̧ir.

Örnek hacmini (anket yapılan tüketici sayısı) belirlemek için aşağıdaki formül kullanılmıştır (Baş, 2008; Gözener ve Say1l1, 2013).

$$
n=\frac{N \times t^{2} \times p \times q}{d^{2} \times(N-1)+t^{2} \times p \times q}
$$

Formülde;

n: Örneğe alınacak birey sayısı,

N: Hedef kitledeki birey sayısı (157 921),

p: İncelenen olayın gerçekleşme olasıllı̆g $1(0,50)$,

q: İncelenen olayın gerçekleşmeme olasilığ $1(0,50)$,

t: Standart normal dağılım değeri $(1,65)$,

$\mathrm{d}$ : Örnekleme hatası $(0,05)$ 'dır.

Formülde $\% 90$ güven aralığ,$\% 5$ hata payı ve maksimum örnek hacmine ulaşabilmek için $p=q=0.5$ olarak alınmış ve örnek hacmi 271 olarak hesaplanmıştır. 
Anketten elde edilen veriler SPSS 17.0 (Statistical Package for Social Sciences) paket programında analiz edilmiştir. Analiz kapsamında, frekans tabloları, grafikler, bağımsız örneklem t testi, Tek Yönlü Varyans (ANOVA) Analizi ve Ki kare testinden faydalanılmıştır. Tek Yönlü Varyans analizinde farklılığın hangi gruplardan kaynaklandığını belirlemek için Duncan testi kullanılmıştır.

\section{Bulgular ve Tartışma}

\section{Anket Yapılan Tüketicilerin Sosyoekonomik ve Demografik Özellikleri}

Tüketicilerin yarıdan fazlasının bayan olduğu ve yarıya yakının 31 yaşından küçük olduğu belirlenmiştir. İlkokul mezunu olan tüketicilerin oranı \%35, ortaokul mezunu olan tüketicilerin oranı $\% 24,7$, lise mezunu olan tüketicilerin oran $1 \% 18,6$, üniversite mezunu olan tüketicilerin oran $1 \% 15,1$ ve yüksekokul mezunu olan tüketicilerin oranı ise \%6,6 olarak tespit edilmiştir. Medeni durum itibariyle anket yapılan tüketicilerin yarıdan fazlasının evli olduğu ve ailedeki birey sayısının 4 kişiden az olduğu sonucu bulunmuştur. Ailedeki birey sayısı ortalama olarak 4,46 kişi olarak hesaplanmıştır. Genel olarak anket yapılan tüketicilerin ailelerinde 2 kişiden az bireyin çalıştığı (ortalama:1,79) belirlenmiştir. 1 çocuğu olan tüketicilerin oran $\% 32,4,2$ çocuğu olan tüketicilerin oranı $\% 28,9$ ve 3 ve daha fazla çocuğu olan tüketicilerin oranı ise \%38,5 olarak bulunmuştur. Ailedeki çocuk sayısı ortalama 2,66 olarak hesaplanmıştır. Tüketicilerin yarıdan fazlasının $(\% 57,6)$ kendi evinde oturduğu ve büyük bir kısmında $(\% 81,5)$ annenin çalışmadığı sonucuna ulaşılmıştır. Anket yapılan tüketicilerin \%59,4'ünün 3001 TL'den daha az gelire sahip olduğu ve aylık gelir ortalamasının 3647,47 TL olduğu saptanmıştır.

\section{Durumu}

Anket Yapılan Tüketicilerin Süt (Açık ve Diğer Sütler) ve Süt Ürünleri Tüketme

Anket yapılan tüketicilerin tamamı bütün süt türlerini ve süt ürünlerini tükettiklerini ifade etmişlerdir. Tüketicilerin \%68,2'sinin açık süt tükettiği belirlenmiştir. Daha önce yapılan çalışmalarda, açık süt tüketilme oranı; Uzundumlu ve Birinci (2013) tarafindan Erzurum'da \% 71,9, Erzincan'da Erdal ve Tokgöz (2011) tarafından \%67,8, Çebi ve ark (2018) tarafindan \%69,9, Niyaz ve İnan (2016) tarafından Çanakkale ve Balıkesir illerinde \%43,4; Ocak ve Önder (2014) tarafından Adana ilinde $\% 4,2$, İstanbul'da Şimşek ve ark. (2005) tarafindan \%11, Karakaya ve Akbay (2013) tarafindan $\% 26,5$, Erbay (2019) tarafindan \%54, Oğuz ve Küçükçongar (2002) tarafından Konya ili Selçuklu ilçesinde \%66,25, Çelik ve ark (2005) tarafından Şanlıurfa'da \%46,3, Demircan ve ark (2011) tarafından Isparta'da \%39, Akbay ve Yıldız Tiryaki (2007) tarafından Kahramanmaraş'ta \%43,4, Kahraman (2016) tarafindan İzmir'de \%8,8, Gözener ve Sayılı (2013) tarafindan Tokat'ta \%84,8, Andiç ve ark (2002) tarafindan Van'da \%64 olarak bildirilmiştir. İller arasındaki bu farklılığın sebebinin; kentleşme yapılarındaki farklılık ve tüketicilerin sosyo demografik ve ekonomik özelliklerinin farklı olmasının doğal bir sonucu olduğu düşünülebilir.

Anket Yapılan Tüketicilerin Gelir Grupları İtibariyle Aylık Gıda Harcaması, Açık Süt Tüketim Miktarı ve Açık Süt Tüketim Harcaması

Gelir grupları itibariyle anket yapılan tüketicilerin aylık gida harcamas1 778,81 TL ile 1820,41 TL arasında değişirken ortalama 1047,30 TL, açık süt tüketim miktarı 11,95 kg ile 18,83 kg arasında ve ortalama 14,24 kg, açık süt tüketim harcaması ise 20,66 TL ile 35,18 TL arasında ve ortalama 31,67 TL olarak belirlenmiştir (Çizelge 1). Gıda harcaması ve açık süt tüketim miktarı ortalamaları arasındaki farklar gelir grupları itibariyle istatistiki olarak önemli bulunmuştur. Gelir arttıkça aylık gıda harcamasının da arttığı belirlenmiştir. Orta gelir grubundaki (3001-5000 TL) tüketicilerin diğer gelir grubundaki tüketicilere göre daha fazla açık süt tükettikleri tespit edilmiştir. Aylık açık süt harcamalarının, aylık toplam gıda harcamaları içindeki payı gelir grupları itibariyle $\% 1,13$ ile $\% 4,45$ arasında değişmekte olup aileler ortalamasında \%3,0 olarak hesaplanmıştır. Aylık gıda harcamaları, gelir arttıkça mutlak olarak artarken, oransal olarak azalmaktadır. Aylık gıda harcamasının aylık ortalama gelir içindeki pay1 $\leq 3000 \mathrm{TL}$ gelir grubunda \%33,7 iken, 3001-5000 TL gelir grubunda $\% 26,3$ ve $\geq 5001$ TL gelir grubunda ise $\% 24,7$ olarak hesaplanmıştır. Anket yapılan tüm aileler için bu oran \%28,7 olup, "2015 ve 2016 Hanehalkı Tüketim Harcaması" anketlerinden elde edilen Türkiye ortalaması olan \%20,2 ve \%19,5 değerlerinden yüksektir (Anonim, 2015 ve 2016). Akbay ve Y1ldız Tiryaki (2007) Kahramanmaraş'ta yaptıkları çalışmada, aylık gıda harcamasının aylık ortalama gelir içindeki payının genel ortalama değerini \%32,6 olarak belirlemişlerdir. Karakaya ve Akbay (2013) tarafından İstanbul'da yapılan bir çalışmada ise ailelerin toplam gelirlerinin \%22,5'ini gıda 
harcamalarına ayırdıkları bildirilmiştir. Aylık ortalama gıda harcaması; Erdal ve Tokgöz (2011) tarafından Erzincan'da yapılan bir çalışmada, 373,92 TL, Çelik ve ark (2005) tarafından Şanlıurfa'da yapılan bir çalışmada, 296,36 TL, Demircan ve ark (2011) tarafindan Isparta'da yapılan bir çalışmada 608,58 TL, Akbay ve Yıldız Tiryaki (2007) tarafından Kahramanmaraş'ta yapılan bir çalışmada 181,79 TL olarak hesaplanmıştır. Gözener ve Sayılı (2013) tarafından Tokat'ta yapılan çalışmada, ortalama gelir 1306,09 TL, ortalama gıda harcaması 341,29 TL ve gıda harcamasının gelir içindeki payı ise \%26,1 olarak tespit edilmiştir. Yıllık açık süt tüketimi 170,88 lt, açık süt tüketim harcaması ise 380,04 TL olarak hesaplanmıştır. Kişi başı yıllık açık süt tüketimi 38,31 lt, aç1k süt tüketim harcaması ise 85,21 TL olarak saptanmıştır. Gözener ve Sayılı (2013) tarafindan Tokat'ta yapılan çalışmada yıllık açık süt tüketimi 258 lt, kişi başı açık süt tüketimi ise 69,12 lt olarak bildirilmiştir. Andiç ve ark (2002) tarafından Van'da yapılan çalışmada yıllık ortalama açık süt tüketim miktarı 243,4 lt olarak bildirilmiştir. Akbay ve Yıldız Tiryaki (2007) tarafından Kahramanmaraş'ta yürütülen çalışmada, yıllık kişi başı açık süt tüketim ortalamasının 26,83 lt olduğu belirlenmiştir.

Çizelge 1. Gelir grupları itibariyle aylık ortalama gelir, gıda harcaması, açık süt tüketim miktarı ve açı süt tüketim harcaması

\begin{tabular}{|l|c|c|c|c|}
\hline Gelir grupları & $\begin{array}{c}\text { Ortalama gelir } \\
(\mathrm{TL})\end{array}$ & $\begin{array}{c}\text { G1da harcaması } \\
(\mathrm{TL})\end{array}$ & $\begin{array}{c}\text { Açık süt tüketim miktarı } \\
(\mathrm{lt})\end{array}$ & $\begin{array}{c}\text { Açık süt tüketim harcaması } \\
(\mathrm{TL})\end{array}$ \\
\hline$\leq 3000$ & $2306,88^{\mathrm{a}}$ & $778,81^{\mathrm{a}}$ & $13,35^{\mathrm{a}}$ & 34,72 \\
\hline $3001-5000$ & $4143,22^{\mathrm{b}}$ & $1092,37^{\mathrm{b}}$ & $18,83^{\mathrm{b}}$ & 35,18 \\
\hline$\geq 5001$ & $7345,92^{\mathrm{c}}$ & $1820,41^{\mathrm{c}}$ & $11,95^{\mathrm{a}}$ & 20,66 \\
\hline Ortalama & 3647,47 & 1047,30 & 14,24 & 31,67 \\
\hline F ve P değeri & 608,05 ve $0,000^{* * *}$ & 44,197 ve $0,000^{* * *}$ & 5,114 ve $0,007 * *$ & 2,771 ve 0,066 \\
\hline
\end{tabular}

a,b,c: Aynı sütunda farklı harflerle gösterilen ortalamalar arasındaki farklar istatistiki olarak önemlidir. ***:p<0,001 **: $\mathrm{p}<0,05$

\section{Açık Süt Satın Alma Tercihini Etkileyen Sosyo-Ekonomik ve Demografik Faktörler}

Anket yapılan tüketicilere sadece bir süt türünü almaları durumunda tercihleri sorulmuş ve tüketicilerin yaklaşı \% \% 15'inin (41 kişi) tercihi açık süt olmuştur. Erkeklerin bayanlara göre az da olsa açık süt tercihinden yana oldukları belirlenmiştir. Lise mezunu olan tüketicilerin diğer tüketicilere göre daha fazla açık süt almayı tercih ettiği belirlenmiştir. Bekâr tüketicilerin açık süt satın alma tercihi evli tüketicilere ve diğer tüketicilere göre daha düşüktür. Medeni durum açısından açık süt satın alma tercihi arasında istatistiki olarak önemli bir ilişki bulunmuştur. Ailede çalışan kişi sayısı ile açık süt satın alma tercihi arasında istatistiki olarak önemli bir ilişki bulunmuş, ailede çalışan kişi sayısı arttıkça açık süt satın alma tercihinin azaldığı sonucu saptanmıştır. En fazla açık sütü satın almayı tercih eden tüketicilerin 2 çocuklu aile yapısında olan tüketiciler olduğu belirlenmiş̧ir. Annenin çalışmadığı ailelerde açık süt satın alma tercihinin, annenin çalıştığ 1 ailelere göre daha yüksek olduğu ve bu durumunda istatistiksel olarak önemli olduğu sonucuna varılmıştır. 41 yaşından büyük olan tüketicilerin 41 yaşından küçük olan tüketicilere göre daha çok açık süt satın almayı tercih ettikleri sonucuna varılmış ve bu durum istatistiki olarak önemli bulunmuştur (Çizelge 2). Demircan ve ark (2011) tarafından Isparta' da yapılan çalışmada, açık süt tercihi ile gelir arasında $\% 10$ hata payına göre, açık süt tercihi ile çocuk sayısı arasında ise $\% 5$ hata payına göre anlamlı bir ilişki tespit edilmiştir. Aynı çalışmada açık süt tercihi ile anne in çalışma durumu arasındaki ilişki ise istatistiki olarak anlamlı çıkmamıştır. Karakaya ve Akbay (2014) tarafından İstanbul'da yapılan çalışmada ise açık süt tercihi ile tüketici geliri arasında istatistiki olarak önemli bir ilişki olmadığı belirlenmiştir. İstanbul'da Karakaya ve Akbay (2013) tarafından yapılan çalışmada, 40 ve 40 yaş üstü tüketicilerin daha çok açık süt tükettiği sonucu tespit edilmiş̧ir. Aynı çalışmada, cinsiyetler itibariyle açı süt tüketim tercihi arasındaki ilişki istatistiki olarak önemli bulunmamıştır. Akbay ve Yıldız Tiryaki (2007) tarafından Kahramanmaraş'ta yapılan çalışmada ailedeki çocuk sayısı ile açık süt tercihi arasındaki ilişki önemli bulunmamıştır. Onurlubaş ve Çakırlar (2016) tarafından Türkiye'nin en büyük 3 ilinde (İstanbul, Ankara ve İzmir) yapılan çalışmada, süt tüketim tercihi ile cinsiyet ve medeni durum arasındaki ilişki istatistiki olarak önemsiz bulunurken, süt tüketim tercihi ile yaş, gelir ve eğitim durumu arasındaki ilişki ise istatistiki olarak önemli bulunmuştur. 
ÇOMÜ Zir. Fak. Derg. (COMU J. Agric. Fac.)

2020: 8 (2): $379-389$

ISSN: $2147-8384$ / e-ISSN: 2564-6826

doi: 10.33202/comuagri.732046

Çizelge 2. Açık süt satın alma tercihini etkileyen sosyo-ekonomik ve demografik faktörler

\begin{tabular}{|c|c|c|c|}
\hline \multirow[b]{2}{*}{ Sosyo - Ekonomik ve Demografik Faktörler } & \multicolumn{3}{|c|}{ Açık süt satın alma tercihi (\%) } \\
\hline & Evet & Hayır & Toplam \\
\hline \multicolumn{4}{|l|}{ Cinsiyet } \\
\hline Bayan & 15,1 & 84,9 & 100 \\
\hline Erkek & 16,8 & 83,2 & 100 \\
\hline Ki kare ve $p$ değeri & \multicolumn{3}{|c|}{0,135 ve 0,714} \\
\hline \multicolumn{4}{|l|}{ Eğitim durumu } \\
\hline İlkokul & 16,6 & 83,4 & 100 \\
\hline Ortaokul & 13,4 & 86,6 & 100 \\
\hline Lise & 26,6 & 73,4 & 100 \\
\hline Yüksekokul & 11,1 & 88,9 & 100 \\
\hline Üniversite & 12,8 & 87,2 & 100 \\
\hline Ki kare ve $\mathrm{p}$ değeri & \multicolumn{3}{|c|}{7,953 ve $0,093^{*}$} \\
\hline \multicolumn{4}{|l|}{ Medeni durum } \\
\hline Evli & 20,5 & 79,5 & 100 \\
\hline Bekâr & 8,8 & 91,2 & 100 \\
\hline Diğer (dul ya da boşanmış) & 18,1 & 81,9 & 100 \\
\hline Ki kare ve $\mathrm{p}$ değeri & \multicolumn{3}{|c|}{6,243 ve $0,044 * *$} \\
\hline \multicolumn{4}{|l|}{ Ailede çalışan kişi sayısı } \\
\hline 1 & 25,4 & 74,6 & 100 \\
\hline 2 & 8,1 & 91,9 & 100 \\
\hline 3 ve üzeri & 6,9 & 93,1 & 100 \\
\hline Ki kare ve $\mathrm{p}$ değeri & \multicolumn{3}{|c|}{31,286 ve $0,000^{* * *}$} \\
\hline \multicolumn{4}{|l|}{ Ailedeki çocuk sayısı } \\
\hline 1 & 14 & 86 & 100 \\
\hline 2 & 19,2 & 80,8 & 100 \\
\hline 3 ve üzeri & 14,4 & 85,6 & 100 \\
\hline Ki kare ve $p$ değeri & \multicolumn{3}{|c|}{11,070 ve 0,136} \\
\hline \multicolumn{4}{|l|}{ Annenin çalışma durumu } \\
\hline Çalışan & 8,3 & 91,7 & 100 \\
\hline Çalışmayan & 17,5 & 82,5 & 100 \\
\hline Ki kare ve $p$ değeri & \multicolumn{3}{|c|}{6,015 ve $0,014 * *$} \\
\hline \multicolumn{4}{|l|}{ Gelir durumu } \\
\hline$\leq 3000$ & 19 & 81 & 100 \\
\hline $3001-5000$ & 6,7 & 93,3 & 100 \\
\hline$\geq 5001$ & 19,1 & 80,9 & 100 \\
\hline Ki kare ve $\mathrm{p}$ değeri & \multicolumn{3}{|c|}{5,035 ve $0,081^{*}$} \\
\hline \multicolumn{4}{|l|}{ Yaş durumu } \\
\hline $18-30$ & 12,2 & 87,8 & 100 \\
\hline $31-40$ & 10,5 & 89,5 & 100 \\
\hline $41-50$ & 39,4 & 60,6 & 100 \\
\hline 51 ve üstü & 20 & 80 & 100 \\
\hline Ki kare ve $p$ değeri & \multicolumn{3}{|c|}{18,721 ve $0,000^{* * *}$} \\
\hline
\end{tabular}




\section{Anket Yapılan Tüketicilerin Açık Süt Hakkındaki Düşünceleri}

Cinsiyet itibariyle anket yapılan tüketicilerin \%41,2'si (106 kişi) açık sütün güvenilir olmadığını, \%26,8'i (69 kişi) açık sütün güvenilir olduğunu ifade ederken açık sütün güvenilir olup olmadığ1 konusunda ise \%31,9'unun (82 kişi) yorumsuz kaldığı belirlenmiştir. Cinsiyetler itibariyle açık süt hakkındaki tüketici düşünceleri arasında istatistiki olarak önemli ilişki bulunmamıştır. Açık sütün güvenilir olduğu düşüncesi ile anket yapılan tüketicilerin medeni durumu arasında istatistiki olarak önemli bir ilişki bulunmuştur. Açık sütü güvenli bulan evli tüketicilerin oranı \%29,1 (39 kişi), güvensiz bulan evli tüketicilerin oranı \%37,3 (50 kişi) ve açık süt hakkında görüş belirtmek istemeyen evli tüketicilerin oranı ise \%33,5 (45 kişi) olarak bulunmuştur. Bekâr olan tüketicilerin büyük bir kısmı (\%47,6 40 kişi) açık sütün güvensiz olduğunu, \%29,7'si bu konu hakkında yorum yapmak istemediğini ve \%22,6's1 ise açık sütün güvenilir olduğunu ifade etmişlerdir. Sonuç olarak bekâr olan tüketicilerin evli olan tüketicilere nazaran açık süte daha az güvendikleri sonucuna varılabilir. 31 yaşından küçük olan bireylerin \%25,4'ü (30 kişi) açık sütün güvenilir olduğunu düşünürken, \%43,2'si (51 kişi) açık sütün güvenilir olmadığını ve \%31,4'ü ise bu konuda görüş bildirmek istemediğini ifade etmişlerdir. 51 yaş ve üstünde olan tüketicilerin açık süte güvenme oranı \%36 (9 kişi), güvenmeme oranı \%40 (10 kişi) ve bu konuda yorumsuz kalma oranı \%24 (6 kişi) olarak belirlenmiştir. Genel sonuç olarak yaş arttıkça açık süte olan güvenin arttığı kanısına varılmıştır. Anket yapılan tüketicilerin eğitim durumları itibariyle açık süt hakkındaki düşünceleri arasında da önemli ilişkiler tespit edilmiştir. İlkokul mezunu olan tüketicilerin \%46,5'inin (41 kişi) açık sütü güvensiz bulduğu, ortaokul mezunu olan tüketicilerin ise \%47,7'sinin (32 kişi) açık sütü güvensiz buldukları belirlenmiştir. Lise mezunu olan tüketicilerin \%36,1'i (13 kişi), yüksekokul mezunu olan tüketicilerin \%24'ü (6 kişi) ve üniversite mezunu olan tüketicilerin ise \%34,1'inin (14 kişi) açık sütü güvensiz buldukları belirlenmiştir. Açık sütün güvenilir olduğuna inanılma oranı $3000 \mathrm{TL}$ ve daha az gelire sahip olan tüketiciler için \%29,6 (43 kişi), 3001- 5000 TL arasında gelire sahip olan tüketiciler için \%24,5 (14 kişi) ve $5001 \mathrm{TL}$ ve üzerinde gelire sahip olan tüketiciler için ise \%20,4 (10 kişi) olarak belirlenmiştir. Tüketicilerin gelirleri arttıkça açık sütün güvenilir olduğuna inanılma oranının azaldığı görülmüş, ancak bu durumun istatistiki olarak önemli olmadığı sonucu bulunmuştur. 3000 TL ve daha az gelire sahip olan tüketicilerin \%48,2'sinin (70 kişi), 3001- 5000 TL arasında gelire sahip olan tüketicilerin \%28'inin (16 kişi) ve $5001 \mathrm{TL}$ ve üzerinde gelire sahip olan tüketicilerin ise \%36,7'sinin (18 kişi) ise açık süte güvenmediği sonucu ortaya çıkmıştır. Düşük $(\leq 3000 \mathrm{TL})$ ve yüksek gelir $(\geq 5001)$ grubunda yer alan tüketicilerin diğer gelir grubunda yer alan tüketicilere göre açık süt konusunda daha yüksek oranda güvensiz oldukları sonucu istatistiksel olarak önemli bulunmuştur. Ailedeki çocuk sayısı ve açık süt hakkındaki tüketici düşünceleri arasındaki ilişkiler istatistiki olarak önemli çıkmıştır. Ailesinde 2 çocuğu olan tüketicilerin açık süte güvenme oranları (\%44,2) (23 kişi) diğer gruptaki tüketicilerden daha yüksek olarak bulunmuştur. 1 çocuklu aileye sahip olan tüketicilerin yarısından fazlasının (\%61,5) (32 kişi) açık süte güvenmediği sonucu ortaya çıkmıştır (Çizelge 3). Genel olarak ankete katılan tüketicilerin \%26,2'sinin aç1k süte güvendiği, \%40,9'unun açı süte güvenmediği ve \%31,9'unun ise bu konu hakkında yorumsuz kaldığı belirlenmiştir. Gözener ve Sayılı (2013) tarafından tokatta yapılan çalışmada açık süte güvenme oranı \%50,44 olarak bildirilmiştir.

Çizelge 3. Anket yapılan tüketicilerin bazı özellikleri itibariyle açık süt ile ilgili düşünceleri arasındaki ilişki

\begin{tabular}{|l|c|c|c|}
\hline \multirow{2}{*}{ Tüketici özellikleri } & \multicolumn{3}{|c|}{ Açık süt hakkındaki tüketici düşüncesi (sayı) } \\
\cline { 2 - 5 } & Güvenilir & Güvenilir değil & \multicolumn{2}{|c|}{ Yorumsuz } \\
Cinsiyet & & & 48 \\
Bayan & 40 & 41 & 34 \\
Erkek & 29 & 106 & 82 \\
Toplam & 69 & 0,162 ve 0,687 & 0,158 ve 0,691 \\
\hline Ki kare ve p değeri & 0,186 ve 0,666 & & 257 \\
\hline Medeni durum & & 50 & 45 \\
Evli & 39 & 40 & 25 \\
Bekâr & 19 & & 84 \\
\hline
\end{tabular}




\begin{tabular}{|c|c|c|c|c|}
\hline $\begin{array}{l}\text { Diğer } \\
\text { Toplam }\end{array}$ & $\begin{array}{l}11 \\
69\end{array}$ & $\begin{array}{c}16 \\
106\end{array}$ & $\begin{array}{l}12 \\
82\end{array}$ & \multirow[t]{2}{*}{$\begin{array}{c}39 \\
257\end{array}$} \\
\hline Ki kare ve $\mathrm{p}$ değeri & 33,808 ve $0,000 * * *$ & 9,970 ve $0,007 * *$ & 5,523 ve 0,063 & \\
\hline \multicolumn{5}{|l|}{ Yaş } \\
\hline $18-30$ & 30 & 51 & 37 & \multirow{6}{*}{$\begin{array}{c}118 \\
67 \\
43 \\
25 \\
253\end{array}$} \\
\hline $31-40$ & 10 & 32 & 25 & \\
\hline $41-50$ & 20 & 13 & 10 & \\
\hline 51 ve üstü & 9 & 10 & 6 & \\
\hline Toplam & 69 & 106 & 78 & \\
\hline Ki kare ve $\mathrm{p}$ değeri & 19,158 ve $0,000^{* * * *}$ & 15,525 ve $0,001 * * *$ & 12,119 ve $0,007^{* * *}$ & \\
\hline \multicolumn{5}{|l|}{ Eğitim durumu } \\
\hline İlkokul & 26 & 41 & 21 & 88 \\
\hline Ortaokul & 16 & 32 & 19 & 67 \\
\hline Lise & 10 & 13 & 13 & 36 \\
\hline Yüksekokul & 9 & 6 & 10 & 25 \\
\hline Üniversite & 8 & 14 & 19 & 41 \\
\hline Toplam & 69 & 106 & 82 & \multirow[t]{2}{*}{257} \\
\hline Ki kare ve $\mathrm{p}$ değeri & 22,687 ve $0,000^{* * * *}$ & 9,616 ve $0,047^{* *}$ & 13,175 ve $0,010^{* *}$ & \\
\hline \multicolumn{5}{|l|}{ Aylık gelir } \\
\hline$\leq 3000$ & 43 & 70 & 32 & 145 \\
\hline $3001-5000$ & 14 & 16 & 27 & 57 \\
\hline$\geq 5001$ & 10 & 18 & 21 & 49 \\
\hline Toplam & 67 & 104 & 80 & \multirow{2}{*}{251} \\
\hline Ki kare ve $\mathrm{p}$ değeri & 1,741 ve 0,419 & 6,964 ve $0,031 * *$ & 15,211 ve $0,000^{* * * *}$ & \\
\hline \multicolumn{5}{|l|}{ Ailedeki çocuk sayısı } \\
\hline 1 & 9 & 32 & 21 & 52 \\
\hline 2 & 23 & 19 & 10 & 52 \\
\hline 3 ve üzeri & 18 & 32 & 26 & 76 \\
\hline Toplam & 50 & 83 & 57 & 190 \\
\hline Ki kare ve $\mathrm{p}$ değeri & 19,594 ve $0,012^{* *}$ & 25,613 ve $0,001 * * *$ & 28,555 ve $0,000 * * *$ & \\
\hline
\end{tabular}

\section{Anket Yapılan Tüketicilerin Açık Süt Satın Alma Nedenlerinin Oransal Dağılımı}

Anket yapılan tüketicilere açık sütü neden aldıkları sorulmuş ve birden fazla cevabın işaretlenmesi ile oluşan sonuçlar Şekil 1'de verilmiştir. Tüketicilerin \%34,1'inin satıcıyı tanıdığı ve güvendiği için, \%29,5'inin hijyenik olmasından dolayı, \%27,2'sinin besin içeriğinden dolayı, $\% 19,1$ 'inin diğer (kolay temin edilebilmesi, kapıya kadar getirilmesi, veresiye imkanı olması vb.) nedenlerden dolayı, \%9,2'sinin kokusuz olmasından dolayı ve \%4,6'sının ise fiyatının uygun olmasından dolayı açık süt satın aldıkları belirlenmiştir. Tüketicilerin sosyo demografik özellikleri itibariyle açık süt alma nedenleri arasında önemli ilişkiler belirlenmiştir. Erkek tüketicilerin bayanlara nazaran açık süt satın alırken besin içeriği faktörünü az da olsa daha ön planda gördügü, bayanların ise açık süt satın alırken diğer (kapıya kadar getirilmesi, kolay ulaşılması) nedenleri daha çok ön planda gördüğü saptanmıştır. İlkokul ve ortaokul mezunu olan tüketicilerin açık süt satın alırken diğer tüketicilere göre satıcıyı tanıma ve güvenme, besin içeriği ve diğer nedenlere daha çok dikkat ettikleri belirlenmiştir. Evli olan tüketicilerin diğer tüketicilere göre açık süt satın alırken kokusuz olmasına, besin içeriğine ve satıcıyı tanıma ve güven faktörlerine daha çok önem verdikleri sonucuna varılmıştır. Ailedeki birey sayısı ile açık süt alma nedenlerinden olan fiyat, kokusuz olması, hijyenik olması, besin içeriği ve diğer nedenler arasında istatistiki olarak önemli ilişki bulunmuştur. Ailedeki birey sayısı 8 kişiden fazla olan tüketicilerin bu faktörlere diğer tüketicilere göre daha çok önem verdikleri belirlenmiştir. Ailedeki birey sayısı ile satıcıyı tanıma ve güven faktörü arasındaki ilişki ise istatistiki 
olarak önemli çıkmamıştır. Evde çalışan sayısının 1 kişi olduğu ailelerin açık süt alırken kokusuz olmasına, besin içeriğine, satıcıyı tanımaya ve diğer nedenlere diğer ailelerden daha çok önem verdikleri saptanmıştır. Sadece 1 çocuğu olan tüketicilerin diğerlerine göre açık süt alırken fiyat ve besin içeriği nedenlerine daha çok önem verdikleri belirlenmiştir. Ailelerde annenin çalışma durumu ile açık süt satın alma nedeni arasındaki ilişki incelenmiş ve çalışmayan annelerin oluşturduğu tüketicilerin açık süt satın alırken hijyenik olmasına daha çok önem verdikleri sonucuna ulaşılmıştır. 3000 TL ve altında gelire sahip olan tüketicilerin diğer tüketicilere göre açık sütü hem kapıya kadar geldiği kolay ulaşım sağladığı hem de hijyenik olduğu için daha fazla satın aldıkları sonucu ortaya çıkmıştır. 40 yaş ve daha küçük yaştaki tüketicilerin açık sütü satın alırken kokusuz olmasına önem verdikleri tespit edilmiştir. Erzurum'da yapılan bir çalışmada, açık süt tüketen bireylerin açık süt alımında; \%50,4'ünün hijyene, \%21'inin üreticiyi tanımaya, \%13,8'inin kokusuz olmasına ve \%9,1'inin fiyatına öncelik verdikleri belirlenmiştir (Uzundumlu ve Birinci, 2013). Erdal ve Tokgöz (2011) tarafindan Erzincan'da yapılan çalışmada, açık sütü tercih eden ailelerin \%24,8'inin beğeni ve alışkanlıklarından, \%22,3'ünün daha kolay temin edildiğinden, \%20,7'sinin daha ekonomik olduğundan, \%19,8'inin daha sağlıklı olduğundan ve \%12,4'ünün ise diğer nedenlerden dolayı bu sütü tercih ettikleri belirlenmiştir. Yine Erzincan'da Çebi ve ark (2018) tarafindan yapılan diğer bir çalışmada ise tüketicilerin $\% 47,8$ 'inin açı sütü sağlıklı olmasından dolayı, \%28'inin beğeni ve alışkanlıktan dolayı, \%15,9'unun kolay bulunmasından dolayı, \%5,1'inin diğer nedenlerden dolayı ve \%3,2'sinin ise ekonomik olduğundan dolayı tercih ettikleri saptanmıştır. Tekirdağ' da Güneş (2019) tarafından yapılan çalışmada, tüketicilerin açık sütü daha doğal bulduğu ve katkı maddesi içermediğini düşündükleri tespit edilmiştir. Çalı̧̧mada ayrıca, kırsala yakın kesimlerde açık süt tüketiminin görüldüğü ve açık süt satın alan kişilerin düzenli olarak açık süt tükettikleri, sütün temiz ve kapıya kadar getirildiği, doğal, katkı maddesinin olmadığı ve güven verdiği sonuçları belirlenmiştir.

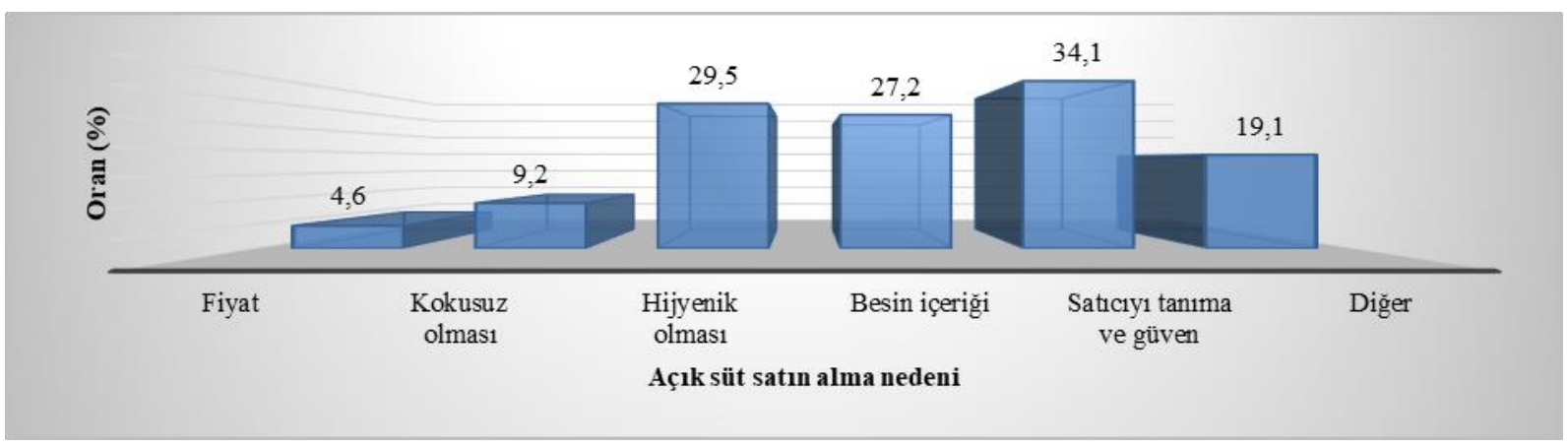

Şekil 1. Açık süt satın alma nedenlerinin oransal dağılımı

\section{Açık Süt Tüketimine Etki Eden Faktörlerin Önem Durumunun Oransal Dağılımı}

Anket yapılan tüketicilere açık süt tüketimine etki eden faktörleri 1'den 5'e kadar numara vererek değerlendirmeleri istenmiş ve elde edilen cevaplar oransal ve ortalama değerler olarak çizelge 4 'te verilmiştir. Anket yapılan tüketicilerin tamamı açık süt tüketimi ile ilgili olan faktörlerin hepsini önemli buldukları belirlenmiştir. Açık sütün fiyatının düşük olması tüketiciler tarafından biraz önemli bulunurken, kapıya kadar getirilmesi, alışkanlığın olması, veresiye imkânının olması ve köyün alıcıya yakın olması faktörleri ise orta derecede önemli olarak bulunmuştur. Tüketicilerin açık süt tüketiminde oldukça önemli olarak gördükleri faktörler; pasta sütlaç yapımına uygun olması ve kaymağının olması faktörleri olarak belirlenmiştir. İnsan sağlığına yararlı olması, tadının güzel olması, üreticiye olan güven, hijyenik olması, yoğurdunun daha güzel olması, katkı maddesi içermemesi ve taze olması faktörleri tüketiciler tarafından çok önemli görülen faktörler olarak tespit edilmiştir. Akbay ve Yıldız Tiryaki (2007) tarafından Kahramanmaraş’ta yapılan çalışmada, anket yapılan tüketicilerin yaklaşık \%50'ye yakınının sokak sütünün veya açık sütün sağlıklı olduğuna inandıkları belirlenmiştir. Isparta ilinde yapılan bir çalışmada, ankete katılan tüketicilerin \%32,5'inin açık sütün sağlıklı olduğunu düşündüğü sonucu tespit edilmiştir (Demircan ve ark., 2011). Tokat'ta yapılan bir çalışmada, açık süt tüketiminin tercih edilme nedenleri; \%87,8 ile yoğurt yapımına uygun olması, $\% 51,7$ ile sağlıklı olması, \%50,4 ile güvenilir olması, \%30 ile taze olması, \%15,6 ile alışkanlık, \%10,4 ile katkısız 
olması, \%5,6 ile temininin kolay olması ve \%4,7 ile de ucuz olması olarak belirlenmiştir (Gözener ve Sayıl1, 2013). Uzundumlu ve Birinci (2013) Erzurum'da yaptıkları çalışmada, tüketicilerin açık sütü tercih etmelerindeki en önemli faktörlerin; açı sütün yoğurdunun daha güzel olması, daha taze olması, pasta, sütlaç vb. yapmaya uygun olması, üreticiye güven, katkı maddesi içermediğine inanma ve açık sütün tadının daha güzel olması olduğu, tüketicilerin açık süt tercih ederken en az önem verdikleri faktörlerin ise; fiyatının düşük olması ve veresiye imkânının olması olduğu tespit edilmiştir. Güneş (2019) tarafından Tekirdağ'da yapılan çalışmada, açık sütün yoğurt yapımına uygun olması, sağl1klı olması ve güvenilir olması düşüncelerinin tüketiciler tarafindan en önemli faktörler olduğu bildirilmiştir.

Çizelge 4. Açık süt tüketimine etki eden faktörlerin önem durumunun oransal dağılımı

\begin{tabular}{|c|c|c|c|c|c|c|c|c|}
\hline \multirow[t]{2}{*}{ İfadeler/katılım durumu } & \multicolumn{8}{|c|}{ Oranlar $(\%)^{*}$} \\
\hline & 1 & 2 & 3 & 4 & 5 & Toplam & Ort. & Değerlendirme \\
\hline Fiyatın düşük olması & 40,2 & 13,7 & 21,6 & 15,8 & 8,7 & 100 & 2,39 & Biraz önemli \\
\hline İnsan sağlığına yararlı olması & 4 & 6,5 & 9,3 & 19,1 & 61,1 & 100 & 4,27 & Çok önemli \\
\hline Tadının güzel olması & 5,6 & 2,8 & 8 & 26,5 & 57 & 100 & 4,27 & Çok önemli \\
\hline Üreticiye olan güven & 2,1 & 0,8 & 4,6 & 19,9 & 72,6 & 100 & 4,60 & Çok önemli \\
\hline Kapıya kadar getirilmesi & 21,5 & 15,9 & 13 & 10,6 & 39 & 100 & $\mathbf{3 , 3 0}$ & Orta önemli \\
\hline Hijyenik olmas1 & 1,7 & 2,9 & 5 & 19,5 & 71 & 100 & 4,55 & Çok önemli \\
\hline Yoğurdunun daha güzel olması & 5,7 & 4,9 & 6,1 & 19 & 64,4 & 100 & 4,32 & Çok önemli \\
\hline Pasta sütlaç yapımına uygun olması & 6,1 & 8,9 & 13,4 & 21,5 & 50,2 & 100 & 4,01 & Oldukça önemli \\
\hline Alışkanlığın olması & 20,9 & 13,1 & 13,1 & 21,3 & 31,6 & 100 & $\mathbf{3 , 3 0}$ & Orta önemli \\
\hline Katkı maddesi içermemesi & 4,5 & 2,4 & 5,3 & 25,9 & 61,9 & 100 & 4,38 & Çok önemli \\
\hline Taze olması & 1,7 & 3,9 & 2,6 & 16,8 & 75 & 100 & 4,59 & Çok önemli \\
\hline Veresiye imkânı & 34,4 & 11,2 & 14,9 & 22,8 & 16,6 & 100 & 2,76 & Orta önemli \\
\hline Köyün yakınlığı & 19,1 & 14,8 & 12,3 & 27,1 & 26,7 & 100 & 3,28 & Orta önemli \\
\hline Kaymağının olması & 11,6 & 4 & 16,9 & 24,5 & 43 & 100 & $\mathbf{3 , 8 3}$ & Oldukça önemli \\
\hline
\end{tabular}

*: 1: önemli değil. 2: biraz önemli. 3: orta önemli. 4: oldukça önemli. 5: çok önemli Ort: Ortalama

\section{Sonuç ve Öneriler}

Tüketicilerin \%59,8'inin bayan olduğu ve \%49,4'ünün 31 yaşından küçük olduğu ve yaş ortalamasının 33 olduğu belirlenmiştir. Tüketicilerin \%35'inin ilkokul mezunu olduğu tespit edilmiştir. Medeni durum itibariyle anket yapılan tüketicilerin \%54,6'sının evli olduğu ve ailedeki birey sayısının ortalama olarak 4,46 kişi olduğu saptanmıştır. Anket yapılan tüketicilerin ailelerinde ortalama olarak 1,79 kişinin çalıştı̆̆ belirlenmiştir. Ailedeki çocuk sayısı ortalama 2,66 olarak hesaplanmıştır. Tüketicilerin yarıdan fazlasının $(\% 57,6)$ kendi evinde oturduğu ve büyük bir kısmında $(\% 81,5)$ annenin çalışmadığı sonucuna ulaşılmıştır. Anket yapılan tüketicilerin aylık gelir ortalamasının 3647,47 TL olduğu saptanmıştır.

Anket yapılan tüketicilerin tamamı bütün süt türlerini ve süt ürünlerini tükettiklerini ifade etmişlerdir. Tüketicilerin \%68,2'sinin açık süt tükettiği belirlenmiştir.

Anket yapılan tüketicilerin aylık gıda harcaması ortalama 1047,30 TL, açık süt tüketim miktarı ortalama 14,24 kg, açık süt tüketim harcaması ise ortalama 31,67 TL olarak belirlenmiştir. Aylık açık 
süt harcamalarının, aylık toplam gıda harcamaları içindeki payı gelir grupları itibariyle aileler ortalamasında \%3 olarak hesaplanmıştır. Aylık gıda harcamasının aylık ortalama gelir içindeki payı, anket yapılan tüm aileler için \%28,7 olarak hesaplanmıştır.

Çalışma sonucunda Bingöl ilinde yıllık açık süt tüketimi 170,88 lt, açı süt tüketim harcaması ise 380,04 TL olarak hesaplanmıştır. Kişi başı yıllık açık süt tüketimi 38,31 lt, açık süt tüketim harcaması ise 85,21 TL olarak belirlenmiștir.

Sadece tek bir süt türünün tercih edilmesi durumunda tüketicilerin yaklaşı \% $\% 15$ 'inin (41 kişi) tercihinin açık süt olacağı belirlenmiştir. Lise mezunu olan tüketicilerin diğer tüketicilere göre daha fazla açık süt satın almayı tercih etmesi, bekâr tüketicilerin, evli tüketicilere ve diğer tüketicilere göre daha az açık süt satın almayı tercih etmeleri istatistiksel olarak önemli bulunmuştur. Ailede çalışan kişi sayısı arttıkça açık süt satın alma tercihinin azaldığı sonucu saptanmıştır. 2 çocuklu aile yapısında olan tüketicilerin, en fazla açık sütü satın almayı tercih eden tüketiciler olduğu belirlenmiştir. Annenin çalışmadığı ailelerde açık süt satın alma tercihinin, annenin çalıştı̆ğ ailelere göre daha yüksek olduğu istatistiksel olarak önemli bir durum olarak saptanmıştır. 41 yaşından büyük olan tüketicilerin 41 yaşından küçük olan tüketicilere göre daha çok açık süt satın almayı tercih ettikleri sonucuna varılmış ve bu durum istatistiki olarak önemli bulunmuştur.

Genel olarak ankete katılan tüketicilerin \%26,2'sinin açık süte güvendiği, \%40,9'unun açık süte güvenmediği ve \%31,9'unun ise bu konu hakkında yorumsuz kaldığı belirlenmiştir. Açık süt hakkındaki düşünce ile tüketicilerin sosyo-demografik ve ekonomik özellikleri arasında cinsiyet bakımından önemli bir ilişki olmadığı, medeni durum, yaş, eğitim, gelir ve ailedeki çocuk sayısı bakımından ise önemli bir ilişki olduğu belirlenmiştir.

Tüketicilerin \%34,1'inin satıcıyı tanıdı̆̆ 1 ve güvendiği için, \%29,5'inin hijyenik olmasından dolayı, \%27,2'sinin besin içeriğinden dolayı, \%19,1'inin diğer (kolay temin edilebilmesi, kapıya kadar getirilmesi, veresiye imkanı olması vb.) nedenlerden dolayı, \%9,2'sinin kokusuz olmasindan dolayı ve $\% 4,6$ 'sının ise fiyatının uygun olmasından dolayı açık süt satın aldıkları belirlenmiştir. Tüketicilerin sosyo demografik özelliklerinin açık süt alma nedenleri üzerinde de önemli etkilere sahip olduğu sonucuna varılmıştır.

Anket yapılan tüketicilerin tamamının açık süt tüketimi ile ilgili olan faktörlerin hepsini önemli buldukları belirlenmiştir. Açık sütün fiyatının düşük olması tüketiciler tarafından biraz önemli bulunurken, kapıya kadar getirilmesi, alışkanlığın olması, veresiye imkânının olması ve köyün alıcıya yakın olması faktörleri ise orta derecede önemli olarak bulunmuştur. Tüketicilerin açık süt tüketiminde oldukça önemli olarak gördükleri faktörler; pasta sütlaç yapımına uygun olması ve kaymağının olması faktörleri olarak belirlenmiştir. İnsan sağlığına yararlı olması, tadının güzel olması, üreticiye olan güven, hijyenik olması, yoğurdunun daha güzel olması, katkı maddesi içermemesi ve taze olması faktörleri tüketiciler tarafından çok önemli görülen faktörler olarak tespit edilmiştir.

Sonuç olarak açık sütün tercih edilme oranının yüksek çıkması hem süt üretimi hem de tüketiminin kayıt altına alınması bakımından zor bir durum ortaya koymaktadır. Bingöl ilinin tarım ve hayvancılığa dayalı ekonomik yapısının iyileştirilmesi için tarımsal üretimde sanayileşme ile ilgili yapılacak çalışmalar bu durumun çözümü için son derece önemlidir. Açık sütün sağl1klı olduğuna dair, ambalajlı sütlerin ise katkı maddesi içerdiğine dair tüketici görüşlerinin dikkate alınarak bu konu ile ilgili uzman kişi ve kurumlarca eğitim ve bilinçlendirme çalışmalarının yapılması gereklidir. Özellikle ambalajlı süt üreten firmaların tüketici isteklerini dikkate alarak yapacakları girişimler ambalajlı süt tüketiminin artmasını sağlayacaktır. Hem Türkiye genelinde hem de Bingöl ili özelinde süt tüketiminin arttırılması için tarım işletmeleri tarafından elde edilen çiğ sütü işleyen modern süt işletmelerinin sayısının arttırılması gerekmektedir.

\section{Kaynaklar}

Akbay, C., Yıldız Tiryaki, G., 2007. Tüketicilerin ambalajlı ve açık süt tüketim alışkanlıklarının karşılaştırmalı olarak incelenmesi: Kahramanmaraş örneği. KSÜ Fen ve Mühendislik Dergisi. 10(1), Kahramanmaraş.

Akbay, C., Y1ldı Tiryaki, G., 2008. Unpacked and packed fluid milk consumption patterns and preferences in Turkey. Agricultural Economics. 38(1):9-20.

Andiç, S., Şahin, K., Koç, Ş., 2002. Süt tüketim yapısı: Van ili kentsel alan örneği. Yüzüncü Yıl Üniversitesi Ziraat Fakültesi Tarım Bilimleri Dergisi. 13(1): 15-21.

Anonim, 2015. Hane Halkı Tüketim Harcaması (Bölgesel), (http://tuik.gov.tr) (Erişim tarihi: 03.05.2020). 
Anonim, 2016. Hane Halkı Tüketim Harcaması (Bölgesel), (http://tuik.gov.tr) (Erişim tarihi: 03.05.2020).

Baş, T., 2008. Anket. Araştırma Yöntemleri Dizisi: 2, Seçkin Yayıncılık, 5. Baskı, Ankara.

Bayat, B., 2014. Uygulamalı Sosyal Bilim Araştırmalarında Ölçme, Ölçekler Ve "Likert" Ölçek Kurma Tekniği. Gazi Üniversitesi İktisadi ve İdari Bilimler Fakültesi Dergisi. 16/3,1-24.

Black, R.E., Williams, S.M., Jones, I.E., Goulding, A., 2002. Children who avoid drinking cow milk have low dietary calcium intakes and poor bone health, The American Journal of Clinical Nutrition. 76(3):675680pp.

Çebi, K., Özyürek, S., Türkyılmaz, D., 2018. Süt ve süt ürünleri tüketiminde tüketici tercihlerini etkileyen faktörler: Erzincan ili örneği. Yüzüncü Y1l Üniversitesi Tarım Bilimleri Dergisi. 28(1): 70-77.

Çelik, Y., Karlı, B., Bilgiç, A., Çelik, Ş., 2005. Şanlıurfa ili kentsel alanda tüketicilerin süt tüketim düzeyleri ve süt tüketim alışkanlıkları. Tarım Ekonomisi Dergisi. 11: 5-12.

Demircan, V., Örmeci, M.Ç., Kızılyar, G., 2011. Isparta ilinde ailelerin ambalajlı ve açık süt tüketim alışkanlıklarının karşılaştırmalı olarak incelenmesi. Süleyman Demirel Üniversitesi Ziraat Fakültesi Dergisi. 6(2): 39-47s.

Erbay, E., 2019. Toplumda çiğ sütün tercih nedenleri ve ambalajlı sütlerle kalite ve sağllk riskleri açısından karşılaştııılması. T.C. Haliç Üniversitesi, Lisansüstü Eğitim Enstitüsü, Beslenme ve Diyetetik Anabilim Dalı, Yüksek Lisans Programı, Yüksek Lisans Tezi, s.160, İstanbul.

Erdal, G., Tokgöz, K., 2011. Tüketicilerin ambalajlı ve açık süt tüketim tercihlerini etkileyen faktörler: Erzincan ili örneği. KMÜ Sosyal ve Ekonomik Araştırmalar Dergisi. 13 (20): 111-115

Gözener, B., Sayılı, M., 2013. Tüketicilerin açık süt ve süt ürünleri tüketim tercihlerinin incelenmesi: TokatTurhal ilçesi örneği. Sosyal Bilimler Araştırmaları Dergisi. 1, 160-175.

Güneş, Y., 2019. Tekirdağ ilinde tüketicilerin süt ve süt ürünlerine yönelik algılarının ve tutumlarının belirlenmesi. T.C. Tekirdağ Namık Kemal Üniversitesi, Fen Bilimleri Enstitüsü, Tarım Ekonomisi Anabilim Dalı, Yüksek Lisans Tezi. S. 81. Tekirdağ.

Kahraman, E.M., 2016. İçme sütü tüketim alışkanlıkları ve marka seçiciliğinde etkili faktörlerin analizi: İzmir ili örneği. Ege Üniversitesi, Fen Bilimleri Enstitüsü, Süt Teknolojisi Anabilim Dalı, Doktora Tezi. s.234. İzmir.

Kaplanoğlu, E., 2014. Mesleki stresin temel nedenleri ve muhtemel sonuçları: Manisa ilindeki SMMM'ler üzerine bir araştırma. Muhasebe ve Finansman Dergisi. Ekim 2014, 131-150.

Karakaya, E., Akbay, C., 2013. İstanbul ilinde tüketicilerin süt ve süt ürünleri tüketim alışkanlıkları. Uludağ Üniversitesi Ziraat Fakültesi Dergisi. 27 (1): 65-77s.

Karakaya, E., Akbay, C., 2014. İstanbul ili kentsel alanda tüketicilerin açık ve paket süt tüketim alışkanlıkları. Tarım Ekonomisi Dergisi. 20(1), 17-27.

Metin, M., 2012. Süt Teknolojisi Sütün Bileşimi ve İşlenmesi. Ege Üniversitesi Rektörlük Yayınları, İzmir, $802 \mathrm{~s}$.

Niyaz, Ö.C., İnan, İ.H., 2016. TR22 Güney Marmara Bölgesindeki tüketicilerin süt ve süt ürünleri tüketim düzeylerinin belirlenmesi. ÇOMÜ Ziraat Fakültesi Dergisi. 4 (2): 7-13

Ocak, S., Önder, H., 2014. Süt ürünlerinde tüketici tercihini etkileyen faktörler ve gıda güvenliği bilinci. Hayvansal Üretim. 55(2): 9-15.

Oğuz, C., Küçükçongar, M., 2002. Konya ili Selçuklu ilçesi hane halkının süt ve süt ürünleri tüketim ve satın alma davranışları. Türkiye V. Tarım Ekonomisi Kongresi, 18-20 Eylül, Erzurum, s. 217-224.

Onurlubaş, E., Çakırlar, H., 2016. Tüketicilerin süt ve süt ürünleri tüketimini etkileyen faktörlerin belirlenmesi üzerine bir araştırma. Çankırı Karatekin Üniversitesi Sosyal Bilimler Enstitüsü Dergisi. 7(1): 217-242.

SETBİR, 2018. Türkiye Süt, Et, Gıda Sanayicileri ve Üreticileri Birliği. (http://www.setbir.org.tr/) (Erişim tarihi: 03.03.2020).

Şimşek, O., Çetin, C., Bilgin, B., 2005. İstanbul ilinde içme sütü tüketim alışkanlıkları ve bu alışkanlıkları etkileyen faktörlerin belirlenmesi üzerine bir araştırma. Tekirdağ Ziraat Fakültesi Dergisi. 2: 23-35.

Ulusal Süt Konseyi, 2018. Türkiye Süt Sektör İstatistikleri Özet Raporu. (https://ulusalsutkonseyi.org.tr) (Erişim tarihi: 03.03.2020).

Uzundumlu, A.S., Birinci, A., 2013. Tüketicilerin açık süt tüketimini etkileyen faktörlerin analizi: Erzurum ili örneği. Alınteri Zirai Bilimler Dergisi. 25(2): 1-12s.

Ünal, R.N., Besler, T., 2012. Beslenmede Sütün Önemi. Sağlık Bakanlığı Yayın No: 727, Ankara, 40s. 